\title{
The influence of asparagus on the growth of probiotic bacteria in orange juice
}

\begin{abstract}
Functional properties of natural food sources create alternative to develop new food product. The consumption of foods and beverages containing probiotic microorganisms is a growing, global consumer trend. The comparative evaluation of orange juice inoculated with Lactobacillus species with known probiotic properties was performed. The prebiotics used in orange juice is raw asparagus root powder. After that measure the growth of bacteria after one day. To measure the growth of probiotic bacteria in orange juice at first measure the absorbance of the orange juice. Next Pour plate was done to observe the growth of probiotic bacteria. To observe the sustainability of probiotics in orange juice these test were done after two or three day's interval. When bacterial colony grows on petri dish biochemical test was conducted and got positive result. Which mean that asparagus influence the growth of probiotic bacteria. This study suggests that asparagus extract exert a positive effect on growth of lactic acid bacteria in orange juice.
\end{abstract}

Keywords: Orange juice; Functional food, Lactobacillus; Prebiotic; Probiotic
Volume 5 Issue I - 2017

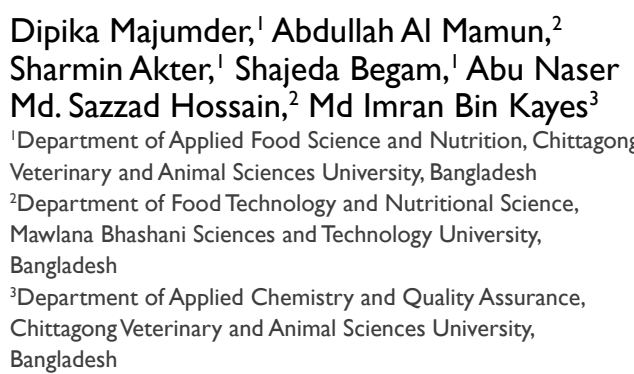

Correspondence: Abdullah AI Mamun, Department of Food Technology and Nutritional Science, Mawlana Bhashani Sciences and Technology University, Tangail, Bangladesh, Tel 8801798327525,Email aamfst@gmail.com

Received: March 17, 2017 | Published: May 17, 2017
Abbreviations: $B, \quad$ Bifidobacterium; FOS, fructooligosaccharides; LAB, lactic acid bacteria; Lb, Lactobacillus; MRS, de man rogosa and sharp

\section{Introduction}

The consumption of foods and beverages containing probiotic microorganisms is a growing, global consumer trend. ${ }^{1}$ The term probiotic is defined as live microorganisms which when administered in adequate amounts confer a health benefit to the host. ${ }^{2}$ Functional food with probiotics, prebiotics and fibers has been available for consumers for years.

Prebiotics are non-digestible food ingredient that beneficially affects the host by selectively stimulating the growth and/or activity of one or a limited number of bacteria already resident in the colon. ${ }^{3}$ that confer benefits upon host wellbeing and health. ${ }^{4}$ Due to this microflora, the colon has the ability to undertake complex hydrolytic digestive functions. ${ }^{5}$ Research has shown that addition of probiotics to food provides several health benefits include reducing the antibiotic destructive effect and regeneration of any type of loss in beneficial microflora; ${ }^{6,7}$ treating diarrheal disorder; ${ }^{8,9}$ improving intestinal tract health ${ }^{10}$ enhancing the immune system, synthesis of the bioavailability of nutrients. ${ }^{11}$; reducing symptoms of lactose intolerance; ${ }^{8}$ reducing the risk of certain cancers; ${ }^{12,13}$ control of serum cholesterol levels; and blood pressure control. ${ }^{14}$ Fruit juice has been suggested as a novel, appropriate medium for fortification with probiotic cultures because it is already positioned as a healthy food product. It has been suggested that fruit juices could serve as suitable media for cultivating probiotic bacteria. $^{15}$

Orange contains vitamin $\mathrm{C}$, considerable amount of sugars, folic acid, potassium and excellent source of bioactive antioxidant.${ }^{16}$ Recent reports suggested that drinking generous amounts of a mixture of various fruit juices improves the blood lipid profile, reduces oxidative stress, prevents atherogenic modifications of Low density lipoprotein
(LDL) cholesterol and platelet aggregation, ${ }^{17-19}$ and improves High density lipoprotein (HDL) cholesterol concentrations. ${ }^{20}$

The most commonly probiotic bacterial genera are Lactobacillus and Bifidobacterium, while yeasts mainly belong to Saccharomyces cerevisiae var. boulardii; different strains from Lactobacillus acidophilus, Lb. casei, Lb. crispatus, Lb. delbrueckii subsp. bulgaricus, Lb. fermentum, Lb. gasseri, $L b$. johnsonii, Lb. paracasei, Lb. plantarum, Lb. reuteri, Lb. rhamnosus, Lb. helveticus, Lb. lactis, B. bifidum, B. breve, B. infantis, B. longum, $B$. lactis, B. adolescentis, B. essensis, B. laterosporus could be considered as main targets used as probiotics both in dairy and nondairy functional foods. ${ }^{21}$

Several strains of $L b$. plantarum, Lb. acidophilus and Lb. casei can grow in fruit matrices due to their tolerance to acidic environments; where orange juice was proved to be a suitable media for prolonged survival of Lb. casei, Lb. rhamnosus, Lb. paracasei. ${ }^{22,23}$ Fructooligosaccharides (FOS) and inulin selectively stimulate the growth of Bifidobacterium and Lactobacillus. ${ }^{24,25}$ which are considered to be beneficial for human health. FOS naturally occur in large number of foods in varying concentration such as onion, asparagus, wheat, banana, rye, triticale and garlic. ${ }^{26,27}$ Asparagus is a great source of prebiotics. Asparagus has been shown to promote friendly bacteria in the gut and has been linked to the prevention of certain cancers. ${ }^{28}$

Lactic acid bacteria (LAB) produce lactic acid as their major fermentation product. The largest genus in this order is Lactobacillus which contains almost 80 species and is used in differentiation products such as pickle, sauerkraut, beer, wine, juices, cheese, yogurt, and sausage..$^{29}$ LAB are useful probiotics. Their beneficial effects were revealed by a Russian Scientist $E$. Metchnikoff (1845-1919) who proposed that extended longevity of people of Balkan could be attributed to their practice of ingesting fermented milk products. ${ }^{30}$ 


\section{Materials and methods}

\section{Design of the experiment}

Thestudy was divided intothreesteps. The firststepincludes isolation of microorganisms from collected samples (desired microorganism was LAB such as Lactobacillus and Lactococcus species). The second step involves identification of isolates by biochemical tests. The third step involves observation of the isolates for probiotic properties.

\section{Isolation of microorganisms}

Sample preparation: Dahi is a natural medium for microbial growth. The Dahi were collected from Baluchara bazar, Chittagong, Bangladesh. Dahi sample (25g) was taken aseptically into stomacher bag, and then $225 \mathrm{ml}$ MRS (de Man, Rogosa and Sharp) broth medium was added. After blending for 20 seconds using stomacher machine, it was aseptically transferred to the homogenized mixture into sterile Schott bottle. The stomacher bag was incubated at $37^{\circ} \mathrm{C} \pm 1^{\circ} \mathrm{C}$ for 18 to 24 hours in anaerobic chamber.

Media and isolation technique: MRS Media has been used enormously in the enumeration and isolation of lactic acid bacteria. Pour plate technique was applied for enumeration and isolation of bacteria. The samples were diluted up to $10-6 .{ }^{31}$

McIntosh and Filde's anaerobic jar: McIntosh and Filde's anaerobic jar is used in anaerobic environment. This method of anaerobiosis others is used to culture bacteria which die or fail to grow in presence of oxygen. ${ }^{32}$

Method of use: In an air-tight gas jar the culture media, the gas-pak sachet (opened and water added) and an indicator were placed. The culture media are placed inside the jar, stacked up one on the other, and jar is incubated at the desired temperature. The indicator tells whether the environment was indeed oxygen free or not. ${ }^{32}$

\section{Morphological and cultural studies of selected isolates}

The selected isolates were streaked on MRS agar medium for their morphological characters such as size, shape, edge, elevation, opacity, surface and color of the colony. The modes of bacterial growth on MRS agar slants such as rhizoidal, spreading, echinulate, filiform, arborescent and adherent or slimy were studied. The purified isolates were then maintained on the nutrient agar slants and preserved as stock culture in refrigerator at $4^{\circ} \mathrm{C}$. For the study of size and shapes of the vegetative cells microscopic method was used. Gram staining was performed as per procedures described by Merchant and Packer. ${ }^{33}$

\section{Biochemical Tests of the Selected Isolates}

Biochemical tests were determined according to methods in Bergey,s Manual of Systematic Bacteriology. ${ }^{34}$

Catalase test: A small amount of the colony (pure culture colonies) was transferred from the agar to the surface of a clean, dry glass slide with the help of an inoculating loop or a wooden applicator stick. After that 1 drop of $3 \%$ hydrogen peroxide was placed on to the organism on the slide. Production of bubbles was indicates the positive result of oxygen production.

Oxidase test: Loopful oxidase reagent was mixed with $10 \mathrm{ml}$ distilled water and soaked a piece of filter paper in the reagent solution ( $1 \%$ solution of tetra methyl-p-phenylenediamine hydrochloride). Some fresh growths were scraped from the culture plate with a disposable loop or stick and rubbed onto the filter paper or touched a colony with edge of paper. Development of a blue color was indicates positive result of oxidase production.

Citrate Utilization: The ability to utilize citrate as sole source of carbon and energy can be used to distinguish certain gram negative rods. Simmon's Citrate Agar medium was inoculated with small amount of 48 to 72 hours old cultures and incubated at 370C for 48 hours. The alkaline $\mathrm{pH}$ turns the $\mathrm{pH}$ indicator (bromthymol blue) from green to blue was a positive result.

Triple Sugar Iron (TSI) Agar: TSI agar, a tube differential medium, was used to determining carbohydrate fermentation and $\mathrm{H} 2 \mathrm{~S}$ production. Gas from carbohydrate metabolism was also detected. Bacteria could metabolize carbohydrates aerobically (with oxygen) or fementatively (without oxygen) and TSI was used to differentiate bacteria based on their fermentation of lactose, glucose and sucrose and on the production of H2S. TSI agar was used in the identification of the gram-negative bacteria.

\section{MIU (Motility, Indole and Urease) Semi-Solid Agar test}

A test tube was inoculated by stabbing the medium with a loop that had touched the surface of the center of a colony. After 18-24 hours of incubation and examined as:

Motility: positive for diffused growth around the stabbing line;

Urease: positive for violet-red color developed and negative for no color change;

Indole: Added 2-3 drops of Kovacs' Reagent to the culture and formation of a red-violet ring indicates positive where pale yellow color of the reagent for negative.

\section{Assay of antibiotic sensitivity pattern}

To assess the antibiotic sensitivity pattern disk diffusion method was used. Mueller Hinton plates were prepared and swabbed with suspension of selected isolates with the help of sterile cotton bud. After swabbing the antibiotic disks (Amoxycillin, Kanamycin, Nalidixic acid, Streptomycin, Ciprofluxacin, Chloramphenicol, Erythromycin, Tetracycline, Ceftazidime and Sulphamethoxazole) were placed on the surface of the plate at equidistance. The plates were then kept at $4^{\circ} \mathrm{C}$ for 1-2 hours for proper diffusion of antibiotics. The plates were then incubated for $18-24$ hours at $37^{\circ} \mathrm{C}$. The zone of inhibition was observed for antibiotic sensitivity or resistance and zone diameter was measured. ${ }^{35}$

\section{Observation of the isolates for probiotic properties}

Preparation of prebiotics: Raw asparagus roots and ginger were properly washed with water, dried in hot air oven and grinded by grinding machine separately. Then two powders were mixed properly and $1 \%, 2 \%$ and $3 \%$ mixed powder was taken in 3 screw cap test tubes which contain MRS broth. These test tubes were then sterilized. After cooled at room temperature probiotic bacteria were inoculated which were isolated from dahi and incubate these test tubes for $24 \mathrm{hr}$ at $370 \mathrm{C}$. After 1 day, observed the growth of bacteria which was measured by UV-Spectrophotometer. At first from every test tube, upper liquid were collected in another 3 test tube. Then centrifuge these liquid for obtaining a clear solution. After that measure the absorbance of these liquid (Table 1).

Preparation of pest: From pest no 1, took some loop of pest into normal saline water solution water solution and add probiotic bacteria which were isolated from dahi. In pest 2 isolated probiotic bacteria 
were rubbed into it. From pest 2, some loop of pest was taken into grape juice. From these solutions, pour plate method was conducted again with the use of MRS agar and incubate these on anaerobic jar. After 1day growth of bacteria observed i.e., the prebiotics used in juice and normal saline solution support the growth of probiotic (Table 2).

Table I Absorbance of liquid

\begin{tabular}{ll}
\hline Control & $\mathbf{0 . 4 I} \mathbf{~ I}$ \\
\hline $\mathrm{I} \%$ & $0.5 \mathrm{I} 3$ \\
$2 \%$ & 0.467
\end{tabular}

Table 2 Prepared two pastes with asparagus and ginger powder

\begin{tabular}{llll}
\hline Paste I & & Paste 2 & \\
\hline Ingredients & Amount & Ingredients & Amount \\
\hline Asparagus & $2.5 \mathrm{gm}$ & Asparagus & $2.5 \mathrm{gm}$ \\
Ginger & $0.5 \mathrm{gm}$ & Ginger & $0.5 \mathrm{gm}$ \\
Starch & $0.25 \mathrm{gm}$ & Cassava Starch & $0.25 \mathrm{gm}$ \\
Sucrose & $0.25 \mathrm{gm}$ & Sucrose & $0.25 \mathrm{gm}$ \\
Glucose & $0.25 \mathrm{gm}$ & Glucose & $0.25 \mathrm{gm}$ \\
Galactose & $0.25 \mathrm{gm}$ & Galactose & $0.25 \mathrm{gm}$ \\
Water & $15 \mathrm{ml}$ & Water & $15 \mathrm{ml}$ \\
Total & $5 \mathrm{gm}$ & Total & $5 \mathrm{gm}$ \\
\hline
\end{tabular}

Preparation of orange juice: Orange juice was prepared manually to add prebiotic which support the growth of probiotic bacteria. To prepare orange juice sodium benzoate (as preservative), citric acid (as tartness) and dextrose (for sweetness) were added. Then $600 \mathrm{ml}$ of orange juice was divided in 3 bottles which are sterilized before. One bottle contains only juice which is used as control. Another bottle contains juice, prebiotics and isolated probiotic bacteria. And the last bottle contains juice, extract of asparagus powder \& ginger powder and isolated probiotic bacteria.

Pour plate method: After preparation of orange juice these are kept in an incubator for 1day. For 2nd and 3rd bottle pour plate technique were applied to measure the growth of probiotic bacteria. These petri plates were kept in anaerobic jar for 1day and then growth of probiotic bacteria were observed. Lastly pour plate technique applied to 3rd bottle of juice after 2day because the color, flavor of the juice was great. To measure the susceptibility of Lactobacillus $s p$ in this petridish oxidase and catalase test were done.

\section{Probable innovation}

In this study, the susceptibility range of Lactobacillus $s p$ in orange juice with asparagus as a prebiotic is the possible outcome.

\section{Results}

\section{Isolation and identification of bacteria}

The collected samples were inoculated into MRS broth in conical flask and incubated at $37 \mathrm{oC}$ for overnight. After overnight incubation at $37^{\circ} \mathrm{C}$, opaque white colored cultures were chosen for the growth of Lactobacillus and Lactococcus. Culture from MRS broth was then inoculated on MRS agar plates. After overnight incubation at $37^{\circ} \mathrm{C}$, pure white colored colonies were tentatively chosen to be Lactobacillus and Lactococcus by observing their colony morphology, physiological and as well as some biochemical characteristics. Microscopically they are Gram-positive, rod or cocci shaped non-motile, catalase negative and absence of Endospore.

\section{Characterization and identification of the selected isolates}

The purposes of identification are to place the microorganism into a specific class or group so that characteristics of these unknown organisms can be compared with others. All the selected strains were tested for their morphological, cultural and biochemical characters: the characters were compared with the standard description of Bergey,s Manual of Systematic Bacteriology(2nd edition) and found that the isolates were belong to the genera Lactococcus and Lactobacilli. Presumptively selected colonies were repeatedly streaked on the respective selected media (MRS agar) to check and confirm their purity. For biochemical characterization, a series of biochemical tests selective for Lactobacillus and Lactococci $s p$. were performed with the suspected Gram-positive, rod, cocci shaped bacteria. All biochemical test result given in (Table 3).

\section{Assay of antibiotic susceptibility pattern}

Antibiotic sensitivity pattern of the selected isolates were also determined to observe the inhibitory effect of any antibiotics against them. Combination of this type of antibiotic with probiotic organism may destroy the therapeutic activity of the probiotic. Antibiotic Sensitivity pattern of the selected isolates given below (Table 4).

Table 3 Morphological, physiological and biochemical test for identification of isolated Lactobacilli sp

\begin{tabular}{|c|c|c|c|c|c|c|c|c|c|c|}
\hline \multirow{2}{*}{ Sample Code } & \multirow{2}{*}{ Gram Stainig } & \multicolumn{3}{|l|}{ T.S.I } & \multirow{2}{*}{$\begin{array}{l}\text { M } \\
\text { Test }\end{array}$} & \multirow{2}{*}{$\begin{array}{l}\text { I } \\
\text { Test }\end{array}$} & \multirow{2}{*}{$\begin{array}{l}\text { U } \\
\text { Test }\end{array}$} & \multirow{2}{*}{$\begin{array}{l}\mathbf{0} \\
\text { Test }\end{array}$} & \multirow{2}{*}{$\begin{array}{l}\text { C } \\
\text { Test }\end{array}$} & \multirow{2}{*}{$\begin{array}{l}\text { Cit } \\
\text { Test }\end{array}$} \\
\hline & & H2S & Butt & Slant & & & & & & \\
\hline DI & + & - & - & - & - & - & - & - & - & - \\
\hline D2 & + & - & - & - & - & - & - & - & - & - \\
\hline D3 & + & - & + & - & - & - & - & - & - & - \\
\hline D4 & + & - & - & + & - & - & - & - & - & - \\
\hline D5 & + & - & - & + & - & - & - & - & - & + \\
\hline D6 & + & - & - & - & - & - & - & - & - & - \\
\hline D7 & + & - & - & - & - & - & - & - & - & - \\
\hline D8 & + & - & + & - & - & - & - & - & - & - \\
\hline D9 & + & - & - & - & - & - & - & - & - & - \\
\hline DIO & + & - & + & + & - & - & - & - & - & + \\
\hline DII & + & - & - & - & - & - & - & - & - & - \\
\hline $\mathrm{D} / 2$ & + & - & - & - & - & - & - & - & - & - \\
\hline
\end{tabular}

Note: +: Positive; -: Negative; T. S. I.:Triple Sugar Iron; M Test: Motility Test; O Test: Oxidase Test; I Test: Indole Test; U Test: Urease Test; Cit Test: Citrate Test; C Test: Catalase Test 
Table 4 Antibiotics sensitivity of isolated Lactobacilli sp

\begin{tabular}{|c|c|c|c|c|c|c|c|}
\hline $\begin{array}{l}\text { Sample } \\
\text { Code }\end{array}$ & $\begin{array}{l}\text { Amoxycillin } \\
(A M L)(10 \mu g)\end{array}$ & $\begin{array}{l}\text { Nalidixic } \\
\text { Acid(NA) }(30 \mu g)\end{array}$ & $\begin{array}{l}\text { Streptomycin } \\
(\mathrm{S})(10 \mu \mathrm{g})\end{array}$ & $\begin{array}{l}\text { Tetracycline } \\
(T E)(30 \mu g)\end{array}$ & $\begin{array}{l}\text { Ciprofloxacin } \\
(\mathrm{CIP})(5 \mu \mathrm{g})\end{array}$ & 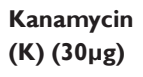 & $\begin{array}{l}\text { Sulphamethoxazole(SXT) } \\
(25 \mu \mathrm{g})\end{array}$ \\
\hline DI & $\mathrm{R}$ & $\mathrm{R}$ & $\mathrm{R}$ & $12 \mathrm{~mm}$ & $\mathrm{R}$ & $10 \mathrm{~mm}$ & $\mathrm{R}$ \\
\hline D2 & $\mathrm{R}$ & $\mathrm{R}$ & $\mathrm{R}$ & $\mathrm{R}$ & $10 \mathrm{~mm}$ & $\mathrm{R}$ & $\mathrm{R}$ \\
\hline D3 & $\mathrm{R}$ & $\mathrm{R}$ & $\mathrm{R}$ & $\mathrm{R}$ & $\mathrm{R}$ & $8 \mathrm{~mm}$ & $R$ \\
\hline D4 & $\mathrm{R}$ & $\mathrm{R}$ & $\mathrm{R}$ & $\mathrm{R}$ & $1 \mathrm{Imm}$ & $R$ & $\mathrm{R}$ \\
\hline D5 & $\mathrm{R}$ & $\mathrm{R}$ & $\mathrm{R}$ & $10 \mathrm{~mm}$ & $\mathrm{R}$ & $\mathrm{R}$ & $\mathrm{R}$ \\
\hline D6 & $\mathrm{R}$ & $\mathrm{R}$ & $\mathrm{R}$ & $\mathrm{R}$ & $\mathrm{R}$ & $\mathrm{R}$ & $\mathrm{R}$ \\
\hline D7 & $\mathrm{R}$ & $\mathrm{R}$ & $\mathrm{R}$ & $\mathrm{R}$ & $\mathrm{R}$ & $12 \mathrm{~mm}$ & $\mathrm{R}$ \\
\hline D8 & $\mathrm{R}$ & $\mathrm{R}$ & $R$ & $\mathrm{R}$ & $\mathrm{R}$ & $\mathrm{R}$ & $\mathrm{R}$ \\
\hline D9 & $\mathrm{R}$ & $\mathrm{R}$ & $\mathrm{R}$ & $R$ & $15 \mathrm{~mm}$ & $\mathrm{R}$ & $\mathrm{R}$ \\
\hline DIO & $\mathrm{R}$ & $\mathrm{R}$ & $\mathrm{R}$ & $10 \mathrm{~mm}$ & $\mathrm{R}$ & $10 \mathrm{~mm}$ & $\mathrm{R}$ \\
\hline DII & $\mathrm{R}$ & $\mathrm{R}$ & $\mathrm{R}$ & $\mathrm{R}$ & $\mathrm{R}$ & $\mathrm{R}$ & $\mathrm{R}$ \\
\hline DI2 & $\mathrm{R}$ & $\mathrm{R}$ & $\mathrm{R}$ & $\mathrm{I} \mathrm{Imm}$ & $\mathrm{R}$ & $11 \mathrm{~mm}$ & $R$ \\
\hline
\end{tabular}

Note: $\mathrm{R}=$ Resistance

\section{Pour plate method}

From the 3rd juice I have done pour plate. At first samples were taken in sterilized petridish. MRS agar was poured into it. Then solidified them at room temp and kept in an anaerobic jar for 2day to observe the growth of bacteria. After 2 days I observed the colony of bacteria in petridish.

\section{Discussion}

For isolation of lactic acid bacteria, Dahi sample was collected from Baluchara bazar, Chittagong. Lactic acid bacteria (Lactobacillus $s p$.) was identified from the dairy samples and assessments of their in vitro characteristics. $\mathrm{pH}$ is an important factor which can dramatically affect bacterial growth. In our experimental design we have observed the growth of our isolated Lactobacillus sp. in various $\mathrm{pH}$ value ranges $(3,3.5,4.0$ and 4.5). The reasons for choosing this $\mathrm{pH}$ range was to determine whether LAB species can grow in acidic and alkaline conditions and also to evaluate the optimum $\mathrm{pH}$ value for good growth and best antimicrobial activity. The result show that all the isolates grew best at $\mathrm{pH} 4.5$ used range value. Growth increases with the increasing of $\mathrm{pH}$ from $\mathrm{pH}-3$ to $\mathrm{pH}-4.5$ but growth decrease when it exceeds the neutral range of $\mathrm{pH}$. Rashid et al. ${ }^{36}$ found that Lactobacillus delbrueckii subsp. Bulgaricus, Lactococcus lactis subsp. Lactis, Lactococcus raffinolactis, Enterococcus faecium, Pediococcus pentosaceus can tolerate $\mathrm{pH}$ up to 5.0. The present results are closely related to their findings. Final $\mathrm{pH}$ measurement also indicates that slight $\mathrm{pH}$ change occurs after incubation of the isolates. It may be due to higher growth of the isolates resulting in the production of greater amount of lactic acid at $\mathrm{pH}-7$. Lactobacillus plantarum could produce lactic acid and reduce the $\mathrm{pH}$ to values lower than 4.0. After growth at different temperature i.e. $27^{\circ} \mathrm{C}, 37^{\circ} \mathrm{C}$ and $45^{\circ} \mathrm{C}$, it was found that the isolates grew best at $37^{\circ} \mathrm{C}$ but Lactobacillus sp can grew at $450 \mathrm{C}$ and show suitable for best antimicrobial activity. Lactic acid bacteria can grow at temperatures from $5-45^{\circ} \mathrm{C}$ and not surprisingly are tolerant to acidic conditions, with most strains able to grow at $\mathrm{pH} 4.4$.

Lactic acid bacteria from fermented products may act as a reservoir of antimicrobial-resistance genes. ${ }^{37}$ In the case of Lactobacillus sp., From the Table 4, 10 tested antibiotics sensitivity pattern shows that isolate Lactobacillus sp. is resistance to Kanamycin, Ciprofloxacin, Streptomycin, Amoxicillin, Nalidixic acid(NA),Tetracycline, Sulphamethoxazole. Resistance to antibiotics is very beneficial to use the isolates Lactobacillus $s p$. as probiotics. Such resistance to a wide spectrum of antibiotic therapy may be helpful in faster recovery of the patients due to rapid establishment of desirable microbial flora.

In this study asparagus were used to support the growth of probiotic bacteria and the orange juice were observed after 2 and 3 days interval and done pour plate. When bacterial colony grows on this Petridish, conducted biochemical test and got positive result. Which mean that asparagus influence the growth of probiotic bacteria.

\section{Conclusion}

Lactic acid bacteria (LAB) are a heterogeneous group of bacteria found widely in nature. They colonize the gastro intestinal tracts of humans and animals, and are present in foods such as dairy products, fermented meats, fruits and vegetables. LABs are also intentionally added to several probiotic products because of their potential health benefits. Dahi is a potential source of probiotic Lactobacilli sp. A total of 30 isolates were primarily isolated and finally identified Lactobacilli $s p$. In conclusion, the experimental results showed that the selected isolate suitable temperature for their growth is showed at $370 \mathrm{C}$ and $\mathrm{pH}-4.5$. The resistance against various antibiotics suggest that my identified Lactobacilli sp. potentially to be used as a probiotic. From the experimental results of tested antibiotics showed that Lactobacilli $s p$. was resistant to Amoxicillin, Nalidixic acid, Streptomycin, Tetracycline, Ciprofloxacin, Kanamycin, Sulphamethoxazole. In spite of the problems with dosage and viability of probiotic strains, lack of industry standardization and potential safety issues, there is obviously considerable potential for the benefits of probiotics over a wide range of clinical conditions. Further study on these isolates will help to detect the genes responsible for therapeutic activities and this type of research will help to design more probiotic agents to control numerous diseases and at the same time it will ensure the safe and healthy human civilization.

\section{Acknowledgements}

The author would also like to express her deep sense of gratitude and thanks to all people at BCSIR (Bangladesh Council of Scientific and Industrial Research), Chittagong, Bangladesh.

\section{Conflicts of interest}

There is no conflict of interest. 


\section{Funding}

None.

\section{References}

1. Verbeke W. Consumer acceptance of functional foods: Sociodemographic cognitive and attitudinal determinants. Food Qual Prefer. 2005;16(1):45-57.

2. Reid G, Jass J, Sebulsky MT, et al. Potential uses of Probiotics in clinical practice. Clin Microbiol Rev. 2003;16(4):658-672.

3. Gibson GR, Roberfroid MB. Dietary modulation of the human colonic microbiota: Introducing the concept of prebiotics. $J$ Nutr. 1995;125(6):1401-1412.

4. Gibson GR, Probert HM, Van Loo J, et al. Dietary modulation of the human colonic microbiota: updating the concept of prebiotics. Nutr Res Rev. 2004;17(2):259-275.

5. Cummings JH, Macfarlane GT. The control and consequences of bacterial fermentation in the human colon. $J$ Appl Bacteriol. 1994;70(6):443-459.

6. Bandyopadhyay P, Das Mohapatra PK. Effect of a probiotic bacterium Bacillus circulans PB7 in the formulated diets: on growth, nutritional quality and immunity of Catla catla (Ham.). Fish Physiol Biochem. 2009;35(3):467-478.

7. Cammarota M, De Rosa M, Stellavato A, et al. In vitro evaluation of Lactobacillus plantarum DSMZ 12028 as a probiotic: emphasis on innate immunity. Int J Food Microbiol. 2009;35(2):90-98.

8. Hawrelak J. Probiotics: choosing the right one for your needs. $J$ Aust Traditional Med Soc. 2003;9(2):67-75.

9. Michail S, Abernathy F. Lactobacillus plantarum reduces the in vitrosecretory response of intestinal epithelial cells to enteropathogenic Escherichia coli infection. $J$ Pediatr Gastroenterol Nutr. 2002;35(3):350-355.

10. Vanderhoof JA. Probiotics and intestinal inflammatory disorders in infants and children. J Pediatr Gastroenterol Nutr. 2000;30(suppl 2):S34-S38.

11. MacFarlane GT, Cummings JH. Probiotics, infection and immunity. Curr Opin Infect Dis. 2002;15(5):501-506.

12. Mego M, Majek J, Koncekova R, et al. Intramucosal bacteria in colon cancer and their elimination by probiotic strain Enterococcus faecium M-74 with organic selenium. Folia Microbiol (Praha). 2005;50(5):443447.

13. Thirabunyanon M, Boonprasom P, Niamsup P. Probiotic potential of lactic acid bacteria isolated from fermented dairy milks on antiproliferation of colon cancer cells. Biotechnol Lett. 2009;31(4):571-576.

14. Hlivak P, Odraska J, Ferencik M, et al. One-year application of probiotic strain Enterococcus faecium M-74 decreases serum cholesterol levels. Bratisl Lek Listy. 2005;106(2):67-72.

15. Mattila T, Sandholm T, Myllarinen P, et al. Technological challenges for future probiotic foods. Int Dairy J. 2002;12:173-182.

16. Vasavada PC. Microbiology of Fruit Juice and Beverage. In: Foster T and Vasada PC (Eds.), Beverage Quality and Safety. 2003;4(2):95-123.

17. Aviram M, Dornfeld L, Rosenblat M, et al. Pomegranate juice consumption reduces oxidative stress, atherogenic modifications to LDL, and platelet aggregation: studies in humans and in atherosclerotic apolipoprotein E-deficient mice. Am J Clin Nutr. 2000;71(5):10621076.

18. Young JF, Nielsen SE, Haraldsdottir J, et al. Effect of fruit juice intake on urinary quercetin excretion and biomarkers of antioxidative status. Am J Clin Nutr. 1999;69(1):87-94.
19. Kurowska EM, Spence JD, Jordan J, et al. HDL-cholesterol-raising effect of orange juice in subjects with hypercholesterolemia. Am J Clin Nutr. 2000;72(5):1095-100.

20. Hallfrisch J, Singh VN, Muller DC, et al. High plasma vitamin C associated with high plasma HDL- and HDL2 cholesterol. Am J Clin Nutr. 1994;60(1):100-105.

21. Ranadheera RDCS, Baines SK, Adams MC. Importance of food in probiotic efficacy. Food Res Int. 2010;43(1):1-7.

22. Peres CM, Peres C, Hernández Mendoza A, et al. Review on fermented plant materials as carriers and sources of potentially probiotic lactic acid bacteria-With an emphasis on table olives. Trends Food Sci Technol. 2012;26(1):31-42.

23. Do Espírito Santo AP, Perego P, Converti A, et al. Influence of food matrices on probiotic viability-A review focusing on the fruity bases. Trends Food Sci Technol. 2011;22:377-385.

24. Tuohy KM, Kolida S, Lustenberger AM, et al. The prebiotic effects of biscuits containing partially hydrolysed guar gum and fructooligosaccharides-a human volunteer study. Br J Nutr. 2001;86(3):341348

25. Holma R, Juvonen P, Asmawi MZ, et al. Galacto-oligosaccharides stimulate the growth of bifidobacteria but fail to attenuate inflammation in experimental colitis in rats. Scand J Gastroenterol. 2002;37(9):10421047.

26. Clevenger MA, Turnbull D, Inoue $\mathrm{H}$, et al. Toxicological evaluation of neosugar: genotaxicity and chronic toxicity. J Am College Toxicol. 1998;5:643-662

27. Van Loo J, Coussement P, de Leenheer L, et al. On the presence of inulin and oligofructose as natural ingredients in the western diet. Crit Rev Food Sci Nutr. 1995;35(6):525-552.

28. Xiang J, Xiang Y, Lin S, et al. Anticancer effects of deproteinized asparagus polysaccharide on hepatocellular carcinoma in vitro and in vivo. Tumour Biol. 2014;35(4):3517-3524.

29. Azizpour K. Biochemical Characterization of Lactic acid Bacteria Isolated from Rainbow Trout (Onorhynchus mykiss) of West Azarbaijn, Iran. Res J Bio Science. 2009;4(3):324-326.

30. Hove H, Nørgaard H, Mortensen PB. Lactic acid bacteria and the human gastrointestinal tract. Eur J Clin Nutr. 1999;53(5):339-350.

31. De Man JC, Rogosa M, Sharpe ME. A medium for the cultivation of lactobacilli. J Appl Bacteriol. 1960;23(1):130-135.

32. Baveja CP. Textbook of Microbiology. Arya Publications, New Delhi, India. 2009:625.

33. Merchant IA, Packer RA. Veterinary Bacteriology and Virology. (7th edn), The Iowa State University Press, Iowa, USA. 1969:211-305.

34. Vos P, Garrity G, Jones D, et al. Bergey,s Manual of Systematic Bacteriology. 2nd edition,Vol-3, the Firmicutes. 2009:465-722.

35. Bauer AW, Kirby WM, Sherris JC, et al. Antibiotic susceptibility testing by a standardized single disk method. Am J Clin Pathol. 1966;45(4):493496.

36. Md Harun-ur-Rashid, Kaname Togo, Minoru Ueda, et al. Probiotic Characteristics of Lactic Acid Bacteria Isolated from Traditional Fermented Milk 'Dahi' in Bangladesh. Pakistan Journal of Nutrition. 2009;6(6):647-652.

37. Mohammed Salim Ammor, Ana Belén Flórez, Angela HAM van Hoek, et al. Molecular Characterization of Intrinsic and Acquired Antibiotic Resistance in Lactic Acid Bacteria and Bifidobacteria. J Mol Microbiol Biotechnol. 2005;14:6-15. 